\title{
PERCEPTIONS OF PARENTS, STUDENTS, AND TEACHERS OF PIKIT NATIONAL HIGH SCHOOL, PIKIT, COTABATO ON THE IMPLEMENTATION OF THE K TO 12 PROGRAM OF THE DEPARTMENT OF EDUCATION
}

\author{
Dialica Laguidong Caup \\ Mindanao State University (MSU), Philippines \\ dcaup@yahoo.com
}

\author{
Al-Jomer Kanapia Buda \\ Mindanao State University (MSU), Philippines
}

\begin{abstract}
This study sought to determine the perceptions of the teachers, students and parents on the K to12 program of the Philippine government. It utilized the descriptive research design in getting the information from the 100 selected respondents (30 teachers, 40 students and 30 parents). The study was conducted at Pikit National High School in Pikit, Cotabato, Philippines. Findings revealed that the parents, students, and teachers appeared to understand the K to 12 program. On the contrary, they still felt there were some areas needing improvements and concerns, like as: $\mathrm{K}$ to 12 programs was expensive, poor, lacking in sufficient facilities, classrooms and laboratory equipment; delays in salary, and insufficient numbers of teachers in Senior High School. In the light of these findings, it is recommended that the Philippine government should allocate sufficient budget for the $\mathrm{K}$ to 12 program to succeed and to allow the stakeholders to share their sentiments about the deficiencies and/or inadequacy of the facilities to accommodate the needs of the growing number of student population all over the country.
\end{abstract}

Keywords: perceptions, the K to 12 program

\section{INTRODUCTION}

The Philippine government implemented the $\mathrm{K}+12$ curriculum starting in 2012 beginning with grade 1 and grade 7 learners and the succeeding levels were introduced as these students get promoted to the next grade levels in the ensuing school year. Prior to this, the Kindergarten Education Act was implemented in school year 2011- 2012 by virtue of Republic Act 10157; the law institutionalized the inclusion of kindergarten education into the basic education system of the Philippines. Subsequently, Republic Act 10533 also known as the "Enhanced Basic Education Act of 2013" enabled the implementation of the K+12 in the country.

The Philippine $\mathrm{K}+12$ curricular program provides at least 1 year of Kindergarten education and a total of 12 years of basic education similar with most of the countries in the world. The addition of 2 years on the former 10 years basic education program was envisioned for mastery of learning making learners better prepared for the world of work besides the conventional belief of just preparing them for collegiate education. The features of the K-12 Enhanced Basic Education Program include the strengthened Science and Math education which follows a spiral progression. The use of spiral progression avoids disjunctions between stages of schooling and allows learners to learn topics and skills appropriate to their developmental and cognitive stages.

The DepEd lays high confidence on the $\mathrm{K}+12$ Program in providing better quality of education that is based on spirally progressing curriculum starting with simple topics moving toward increasing complexity in order for the learners to gain mastery of concepts and skills. Graduates of the $\mathrm{K}+12$ program are therefore envisioned as better prepared to compete globally for employment opportunities. This change on basic education cycle caused the conduct of stakeholder consultations, policy discourses, and education summits to gather inputs and feedback on the educational reform; however the $\mathrm{K}$ to 12 Program remains an issue of inquiries on its implementation and effectiveness. It continuously solicits different responses among various individuals from the students, teachers and parents. The grade 7 students are put to a certain level of confidence performing varied learning activities aided with learning modules in the $\mathrm{K}$ to 12 Program.

On the other hand, the implementation of the $\mathrm{K}+12$ Program remains a formidable matter for schools not well prepared to embrace the program. Teachers are made to adjust to innovative practices integrated in the preparation of lessons, actual delivery of teaching, rating student performances and of the overall classroom management. The parents become aware longer time of schooling that will boil down to more expenses on the education of their children. the impact statements from the immediate beneficiaries of the $\mathrm{K}+12$ Program provide important data on the status of the first implementation of the program in Pikit schools and use such data for monitoring and basis by the technical working groups for curricular review and further enhancement.

\section{Significance of the Study}

This study would be significant to the following groups of individuals:

1. Parents of the Students. This research would be able to help the parents of the students who are affected by the K-12 program, to understand the benefits of the program to their children's academic growth, job skills, and competencies.

2. Students. The students would benefit from the 
study by letting them know how they going to be able to understand the addition of 2 years from their schooling. Students would understand how they would benefit from the program.

3. Teachers. The study would benefit the teachers for them to be prepared for the additional two years to the basic education. It would be important for them to know the advantages and disadvantages of the program, because they would facilitate students' learning and they are the implementers of the program.

4. Pikit National High School (PNHS). This research would also benefit the school, so they would anticipate the additional cost to the program, by hiring additional teachers and providing the needs of the Grade 11 to 12 students.

5. Future Researchers. This study would provide additional information on the perception of parents, students, and teachers on the advantages and disadvantages of the education reform of the government which is the $\mathrm{K}$ to 12 program.

\section{Objectives of the Study}

This study generally aimed to determine the perceptions of the parents, students, and teachers. Specifically, this study aims to:

1. Determine the socio-demographic characteristics of the respondents (parents, students, and teachers);

2. Determine the parents' perceptions on the $\mathrm{K}$ to12 program;

3. Determine the students' perceptions on the $\mathrm{K}$ to 12 program;

4. Determine the teachers' perceptions on the $\mathrm{K}$ to 12 program;

5. Determine the problems encountered by the respondents in the implementation of the $\mathrm{K}$ to 12 programs; and

6. Determine the recommendations of the respondents in the implementation of the $\mathrm{K}$ to 12 programs.

\section{Scope and Limitations of the Study}

This study focused on the perceptions of parents, students, and teachers on the $\mathrm{K}$ to 12 program. It included the socio-demographic characteristics of the respondents. The data for the research was collected in the January 2017 in Pikit National High School, Pikit, Cotabato. The respondents were selected from Pikit National High School, Pikit, Cotabato. The respondents were the parents of the Grade 11 students, the Grade 11 students, and their teachers.

\section{Theoretical Framework}

The historical development of the Philippine basic education program proves the Department's continuing effort at improving the quality and relevance of basic education. In terms of curriculum development, the elementary curriculum underwent three (3) revisions while that of the secondary curriculum underwent four (4) before the $\mathrm{K}$ to 12 curriculums. This is because the introduction of the 2-2
Plan, 2-year college preparatory and 2-year vocational curriculum, was relevant only to the secondary. Like the $\mathrm{K}$ to 12 curriculum, the curricular revisions were backed up by research findings and recommendations. The issue of curriculum congestion which resulted to the learners' lack of mastery of basic competencies was the reason behind the introduction of the decongested New Elementary Education Curriculum (NESC) and New Secondary Education Curriculum (NSEC) in 1983 and 1989, respectively and the 2002 Basic Education Curriculum. For relevance, the 2-2 plan was introduced for the secondary schools in 1958 which was revised in the offering of electives for secondary students in 1973 , to give students choice on career path.

In the 2-2 Plan, both general and vocational secondary schools offered the basic or common curriculum of academic courses with one unit of Practical Arts in the first two years. In the last two years, the general secondary schools offered a precollege academic curriculum with one unit of vocational elective each year while the vocational secondary schools offered more specialized vocational courses with one unit of academic elective each year. The 2-2 Plan was a differentiated curriculum leading either to a college or a technical course. Similar to that of the $\mathrm{K}$ to 12 curriculum, one of the guiding principles of the 2-2 Plan was that - the curriculum of each school should provide vocational courses which are geared to the occupations, resources and industries of the community or region where the school is located.\|9 It was seen to be a very responsive curriculum, however, it was met with strong opposition especially from the private sector which requested for its deferment due to lack of money, facilities, equipment for vocational education and lack of guidance counselors 10 .

The pitfalls of the 2-2 Plan implementation could be attributed to insufficient preparation before the plan was implemented and the continued high 'prestige' value of the college preparatory course in the eyes of parents and students To respond to the need on improving curriculum relevance to increasing diverse contexts of learners as a result of globalization and in addition to the issue of an overcrowded curriculum that haunted basic education, the Department of Education restructured the NESC (1983) and the NSEC (1989) into the 2002 Basic Education Curriculum (BEC). The $2002 \mathrm{BEC}$, the forerunner of the $\mathrm{K}$ to 12 curriculum, is a decongested curriculum consisting of five (5) core learning areas from as many as ten (10).

It had the following objectives: (a) Connect related subjects, (b) Increase the time allotted for Science, English, and Mathematics; (c) Reduce congestion of subjects; (d) Improve attitude towards work to increase productivity; (e) Increase individual's ability to cope in a fast changing world; (f) Increase the importance of the arts, music, sports, dance, and other aspects of Philippine culture; and (g) Develop nationalism among Filipino learners for responsible citizenry. After the introduction of the 2002 BEC, the Bureau of Elementary Education conducted a thorough review of the competencies to enhance the vertical articulation of competencies. In 2010, the Bureau of 
Secondary Education implemented the 2002 BEC based on UbD design for meaningful and integrative teaching. This was called 2010 SEC. This curriculum design is focused on teaching for understanding and on essential and big ideas. It makes use of the-backward design which necessitates determining targets and goals and assessment first before identifying and planning learning activities to ensure clarity of targets.

The issue on lack of mastery of concepts and skills partly due to a congested curriculum did not end even with the already decongested 2002 BEC. This means that the clamor for quality basic education cannot be responded to by mere curriculum decongestion. Thus the $\mathrm{K}$ to $12 \mathrm{Basic}$ Education Program is not only concerned with curriculum decongestion but also with other critical concerns like addressing shortages of educational inputs, improving the quality of teachers and strengthened stakeholders' participation.

The $\mathrm{K}$ to 12 Basic Education Program is a comprehensive program in the sense that the support systems to ensure its implementation - the family and other stakeholders, instructional, administrative and society as a whole are given the needed attention.

\section{Research Design}

This study utilized the descriptive research design in order to determine the socio-demographic characteristics of the respondents and their perceptions on the $\mathrm{K}$ to 12 programs.

Locale of the Study

This study was conducted in Pikit National High School (PNHS), Pikit, Cotabato. Philippines.

\section{Respondents and Sampling Procedure}

The study selected 30 samples from the parentrespondents, 40 for the student-respondents, and 30 for the teacher-respondents. The research selected 30 samples from each group of parents and students through the purposive sampling procedure. However, there was a complete enumeration of the teachers in Pikit National High School, Pikit, Cotabato.

\section{Research Instrument}

The survey questionnaire that was used in this study was specially designed to elicit the perceptions of the parents, students, and teachers on the implementation of the $\mathrm{K}$ to 12 programs in Pikit National High School, Pikit Cotabato. The items in the questionnaires were based on the information provided by the Department of Education and the perceptions of the respondents were elicited by their agreements on each statement. It would also gather data pertaining on the socio-demographic characteristics of the parents, students, and teachers in Pikit National High School, Pikit, Cotabato.

\section{Data Gathering Procedure}

The researcher sought permission from the dean to conduct the surveys in the institute. Next, the researcher presented the permission letter to the target respondents, such as the parents, students, and teachers in Pikit National High School to allow the researcher to gather data from them. Lastly, this data was tabulated, analyzed, and interpreted.

\section{Statistical Analysis}

Frequency distribution and percentage and weighted mean was used to summarize the data gathered such as the socio-demographic characteristics of the respondents and their perceptions on the implementation of the $\mathrm{K}$ to 12 Program in Pikit National High School, Pikit, Cotabato.

\section{RESULTS AND DISCUSSION}

This study entitled, "Perceptions of Parents, Students, and Teachers on the Implementation of the K to 12 Program in Pikit National High School, Pikit, Cotabato", specifically aimed to: (1) determine the socio-demographic characteristics of the respondents (parents, students, and teachers); (2) determine the parents' perceptions on the $\mathrm{K}$ to12 program; (3) determine the students' perceptions on the $\mathrm{K}$ to 12 program; (4) determine the teachers' perceptions on the $\mathrm{K}$ to 12 program; (5) problems encountered by the respondents in the implementation of the $\mathrm{K}$ to 12 programs; and (6) recommendations of the respondents in the implementation of the $\mathrm{K}$ to 12 programs.

\section{A. Socio-demographic Characteristics of the}

\section{Respondents}

Table 1a to 1c present data for the first objective of the study, which was to determine the sociodemographic characteristics of the respondents. There were 100 respondents who were selected to participate in this study. They were distribute to thirty (30) parents, forty (40) Grade 11 students, and thirty (30) teachers in Pikit National High School, Pikit, Cotabato.

\section{Parents' Socio-demographic Characteristics}

Age. Table 1a shows the socio-demographic characteristics of the selected parents of the Grade 11 students of Pikit National High Shoo, Pikit, Cotabato. They were selected using purposive sampling procedure it reveals that majority (i.e. 21 or $70 \%$ ) of the parent-respondents were 36 to 40 years old, $5(16.67 \%)$ were 41 to 45 years old. 3 or $10 \%$ were between 46 to 50 years old, and 1 was within the age range of 31 to 35 years old.

1. Parental Role. Out of 30 parents who were selected, 21 or $70 \%$ of them were mothers and the others were fathers (9 or 30\%).

2. Religious Affiliation. It shows that majority of the respondents belonged to Islam religion or 25 $(83.33 \%)$ and 5 or $16.67 \%$ were Christians.

3. Tribe. In terms of tribe, 23 or $76.67 \%$ were Maguindanaon, 4 or $13.33 \%$ were Ilocano, and the remaining 2 and 1 were Iranun and Ilonggo, respectively.

4. Educational Attainment. The result shows that most (14 or $46.67 \%$ ) of the parents' educational attainment were diploma in high school, 5 or $16.67 \%$ were high school level, 6 for college graduates and Master's degree level, and the remaining three (3) was a college level, elementary and Master's degree holders.

5. Occupation. Based on the finding mentioned 
earlier, nine (9) of the respondents were fathers; hence, their occupations were six (6) farmer, 2 drivers, and 1 carpenter. On the hand, the mothers were mostly housekeepers (i.e. 13 or $43.33 \%$ ) and 8 were government employees.

Table 1a

The Socio-demographic Characteristics of Selected Parents of the Grade 11 Students in Pikit National High School, Pikit, Cotabato (January 2017)

\begin{tabular}{|c|c|c|}
\hline $\begin{array}{c}\text { Socio-Demographic } \\
\text { Characteristics }\end{array}$ & $\begin{array}{c}\text { Frequency } \\
(\mathbf{N}=\mathbf{3 0})\end{array}$ & $\begin{array}{c}\text { Percentage } \\
(\%)\end{array}$ \\
\hline \multicolumn{3}{|l|}{ Age } \\
\hline $31-35$ & 1 & 3.33 \\
\hline $36-40$ & 21 & 70.00 \\
\hline $41-45$ & 5 & 16.67 \\
\hline $46-50$ & 3 & 10.00 \\
\hline \multicolumn{3}{|l|}{ Parental Role } \\
\hline Mother & 21 & 70.00 \\
\hline Father & 9 & 30.00 \\
\hline \multicolumn{3}{|l|}{ Religious Affiliation } \\
\hline Islam & 25 & 83.33 \\
\hline Christianity & 5 & 16.67 \\
\hline \multicolumn{3}{|l|}{ Tribe } \\
\hline Ilocano & 4 & 13.33 \\
\hline Ilongo & 1 & 3.33 \\
\hline Iranun & 2 & 6.67 \\
\hline Maguindanaon & 23 & 76.67 \\
\hline \multicolumn{3}{|l|}{ Educational Attainment } \\
\hline College graduate & 3 & 10.00 \\
\hline College level & 1 & 3.33 \\
\hline Elementary graduate & 1 & 3.33 \\
\hline Elementary level & 2 & 6.67 \\
\hline High School Graduate & 14 & 46.67 \\
\hline High School Level & 5 & 16.67 \\
\hline Master's level & 3 & 10.00 \\
\hline Master's degree holder & 1 & 3.33 \\
\hline \multicolumn{3}{|l|}{ Occupation } \\
\hline Carpenter & 1 & 3.33 \\
\hline Driver & 2 & 6.67 \\
\hline Farming & 6 & 20.00 \\
\hline Government Employee & 8 & 26.67 \\
\hline House Keeper & 13 & 43.33 \\
\hline
\end{tabular}

In general, the parent-respondents were mostly aged 36 to 40 years old, mothers, Islam in religion, Maguindanaon, mostly high school graduates, and housekeepers for female respondents and farmers for male respondents.

\section{Students' Socio-demographic Characteristics}

Strands and Sections, the students who were selected to participate in the study were 40 they were equally (10 for each) selected from the groups of Grade 11 students from the strands and sections of ABM or (Accountancy, Business and Management Strand), Humms (Humanities and Social Sciences Strand), ICT (Information and Communication Technology), and Stem (Science, Technology, Engineering, and Mathematics Strand).
1. Age. Out of 40 student-respondents, more than half ( 21 or $52.50 \%$ ) were 17 years old, $9(22.50 \%)$ were 18 years old, 7 or $17.50 \%$, and 1 and 2 were 14 and 19 years old, respectively.

2. Sex. The result reveals that 31 or $77 \%$ were female students and 9 or $22.50 \%$ were male students.

3. Religious Affiliation. Almost all of the respondents were Islam in religion (36 or $90.00 \%$ ), 3 or $7.50 \%$ Christian, and 1 was unable to specify his/her religious affiliation.

4. Tribe. Maguindanaon emerged as the dominant tribe of the respondents, 3 or $7.50 \%$ for each in Ilonggo and Cebuano tribal groups, while 1 for each Ilocano and Maranao, respectively. 
Table 1b

The Socio-demographic Characteristics of Selected Grade 11 Students in Pikit National High School, Pikit, Cotabato (January 2017)

\begin{tabular}{|c|c|c|}
\hline $\begin{array}{l}\text { Socio-Demographic } \\
\text { Characteristics }\end{array}$ & $\begin{array}{c}\text { Frequency } \\
(\mathrm{N}=40)\end{array}$ & $\begin{array}{c}\text { Percentage } \\
(\%)\end{array}$ \\
\hline \multicolumn{3}{|l|}{ Strands and Sections } \\
\hline Grade 11 - ABM & 10 & 25.00 \\
\hline Grade 11 - Humms & 10 & 25.00 \\
\hline Grade 11 - ICT & 10 & 25.00 \\
\hline Grade 11 - Stem & 10 & 25.00 \\
\hline \multicolumn{3}{|l|}{ Age } \\
\hline 14 & 1 & 2.50 \\
\hline 16 & 7 & 17.50 \\
\hline 17 & 21 & 52.50 \\
\hline 18 & 9 & 22.50 \\
\hline 19 & 2 & 5.00 \\
\hline \multicolumn{3}{|l|}{ Sex } \\
\hline Female & 31 & 77.50 \\
\hline Male & 9 & 22.50 \\
\hline \multicolumn{3}{|l|}{ Religious Affiliation } \\
\hline Islam & 36 & 90.00 \\
\hline Christianity & 3 & 7.50 \\
\hline Others (not specified) & 1 & 2.50 \\
\hline \multicolumn{3}{|l|}{ Tribe } \\
\hline Maguindanaon & 32 & 7.50 \\
\hline Ilonggo & 3 & 2.50 \\
\hline Cebuano & 3 & 7.50 \\
\hline Ilocano & 1 & 80.00 \\
\hline Maranao & 1 & 2.50 \\
\hline
\end{tabular}

In general, the student-respondents were equally selected from the groups of Grade 11 which means 10 for each from the ABM, Humms, ICT, and STEM; mostly 17 years old, female, Islam in religion, and Maguindanaon.

\section{Teachers' Socio-demographic Characteristics}

Table 1c shows the socio-demographic characteristic of the teachers in Pikit National High School who served as teacher-respondents in this study. There were 30 teachers who served as the teacher-respondents in this study. The selection of the teacher was through a complete enumeration because there were exactly 30 teachers in PNHS which coincidentally correspond to the number of teachers needed in the survey.

1. Age. Based on the findings, half of them (15 or $50 \%$ ) were aged between 26 to 30 years old, 7 or $23.33 \%$ were 21 to 25 years old, 4 or $13.33 \%$ were 31 to 35 years old, and 1 in each in the ages between 41 to 45 and 46 to 50 years old.

2. Sex. The findings show that there 15 or $50 \%$ for male and female teacher-respondents in this study.

3. Religion Affiliation. It shows that 19 or $63.30 \%$ of the teachers who participated were Christians, while 11 or $36.66 \%$ Islam.

4. Tribe. It reveals that there were 10 or $33.33 \%$ were Maguindanaon, 8 or $26.70 \%$ were Ilocano, Cebuano were 6 or $20 \%$, and 5 or $16.70 \%$ were Ilonggo, while 1 was an Iranun.

5. Educational Attainment. Data shows that there were
15 or $50 \%$ who was college graduates 11 or $36.66 \%$ were masters level, 3 or $10 \%$ were master's degree holders, and 1 was Ph.D/ Ed.D holder.

6. Position. The findings reveal that 12 or $40 \%$ of the respondents were Teacher 1 in rank, 9 or $30 \%$ were Teacher 2, 8 were Teacher 3 , and only one (1) was a Master Teacher 1.

7. Years in Service. Many of the respondents were within 7-11 months in service (i.e. 14 or $46.50 \%$ ), 5 or $16.70 \%$ had 1 year, and a total of 6 in teacher who served in. 4 and 7 years were between 3 years and one had served in 17 years.

In general, the teacher-respondents were mostly 26 to 30 years old, consisting the same numbers of female and male teachers, Christian in religion mostly Maguindanaon, college graduates, Teacher-1 by rank, and had been working for 7 to 11 months.

\section{B. Parents' Perceptions about the $K$ to 12 Program Implemented in Pikit National High School, Pikit, Cotabato}

There were four (4) tables (Tables $2 \mathrm{a}$ to $2 \mathrm{~d}$ ) used in describing the parent's perception about the $\mathrm{K}$ to 12 program implementation in Pikit, Cotabato. The 4 subscales included: (1) the $\mathrm{K}$ to 12 program, (2) assurance in the employability of the graduate, (3) K to 12 program helps working students in college and students intending to pursue college, and (4) issues on the budget for the $\mathrm{k}$ to 12 program. 
Table 1c

The Socio-demographic Characteristics of Teachers in Pikit National High School, Pikit, Cotabato (January 2017)

\begin{tabular}{|c|c|c|}
\hline $\begin{array}{c}\text { Socio-Demographic } \\
\text { Characteristics }\end{array}$ & $\begin{array}{c}\text { Frequency } \\
(\mathrm{N}=\mathbf{3 0})\end{array}$ & $\begin{array}{c}\text { Percentage } \\
(\%)\end{array}$ \\
\hline \multicolumn{3}{|l|}{ Age } \\
\hline $21-25$ & 7 & 23.33 \\
\hline $26-30$ & 15 & 50.00 \\
\hline $31-35$ & 4 & 13.33 \\
\hline $36-40$ & 2 & 6.67 \\
\hline $41-45$ & 1 & 3.33 \\
\hline $46-50$ & 1 & 3.33 \\
\hline \multicolumn{3}{|l|}{ Sex } \\
\hline Female & 15 & 50.00 \\
\hline Male & 15 & 50.00 \\
\hline \multicolumn{3}{|l|}{ Religious Affiliation } \\
\hline Christianity & 19 & 63.30 \\
\hline Islam & 11 & 36.66 \\
\hline \multicolumn{3}{|l|}{ Tribe } \\
\hline Maguindanaon & 10 & 33.33 \\
\hline Ilocano & 8 & 26.70 \\
\hline Cebuano & 6 & 20.00 \\
\hline Ilonggo & 5 & 16.70 \\
\hline Iranun & 1 & 3.33 \\
\hline \multicolumn{3}{|l|}{ Educational Attainment } \\
\hline College Graduate & 15 & 50.00 \\
\hline Master's Level & 11 & 36.66 \\
\hline Master's Degree Holder & 3 & 10.00 \\
\hline Ph.D. Level/ Ed. D. Level & 1 & $3.33^{`}$ \\
\hline \multicolumn{3}{|l|}{ Position and Rank } \\
\hline Teacher 1 & 12 & 40.00 \\
\hline Teacher 2 & 9 & 30.00 \\
\hline Teacher 3 & 8 & 26.77 \\
\hline Master Teacher 1 & 1 & 3.33 \\
\hline \multicolumn{3}{|l|}{ Years in Service } \\
\hline 7-11 months & 14 & 46.50 \\
\hline 1 year & 5 & 16.70 \\
\hline 3 years & 2 & 6.70 \\
\hline 4 years & 3 & 10.00 \\
\hline 6 years & 2 & 6.70 \\
\hline 7 years & 3 & 10.00 \\
\hline 17 years & 1 & 3.30 \\
\hline
\end{tabular}

\section{Parents Perception about the $K$ to 12 Program}

Table $2 \mathrm{a}$ reveals that there were no extreme findings to emerge because the parent-respondents "agreed" to all of the statements mentioned in the first subscale. The parents seemed to understand that, (1) the $\mathrm{K}$ to 12 offers balanced approach to learning, (2) promote children mastery for competencies they need, (3) children less expenses and increase their children's employability, and (4) children will be equipped with skills, competencies, and recognize certification equivalent to two-year college degree.

Parents' Perception about the Assurance on the Employability of the Graduates

Table $2 b$ shows data for the second subscale of the survey questionnaires for the parents. It reveals that still, consistent with findings is Table $2 \mathrm{a}$, the parentrespondents "agreed" to all of the identified statements for the second subscale which is the assurance on the employability of the graduates. 
Table 2a

Parents' Perceptions about the K to 12 Program Implemented in Pikit National High School, Pikit, Cotabato (January 2017)

\begin{tabular}{clcc}
\hline No & \multicolumn{1}{c}{ The K to 12 Program } & $\begin{array}{c}\text { Weighted } \\
\text { Mean }\end{array}$ & Verbal Description \\
\hline 1 & $\begin{array}{l}\text { I believe that K to 12 offers a more balanced approach to learning that will enable } \\
\text { our children acquire and master lifelong learning skills (as against a congested } \\
\text { curriculum) for the 21st century. }\end{array}$ & 3.26 & Agree \\
2 & $\begin{array}{l}\text { I believe that the current program crams a 12-year curriculum allowing our children } \\
\text { to master the competencies they need. }\end{array}$ & 2.96 & Agree \\
3 & $\begin{array}{l}\text { I believe that K to 12 will help in freeing us of the burden of having to spend for } \\
\text { college just to make our children employable. }\end{array}$ & 3.30 & Agree \\
4 & $\begin{array}{l}\text { I believe that if our children complete K to 12, they will be equipped with skills, } \\
\text { competencies, and recognized certificates equivalent to a two-year college degree. }\end{array}$ & 3.30 & Agree \\
\hline
\end{tabular}

\section{Legend:}

Weighted Mean Verbal Description

$3.50-4.00 \quad$ Strongly Agree

2.50-3.49 Agree

$1.50-2.49 \quad$ Disagree

$1.00-1.49 \quad$ Strongly Disagree

It implies that the parents understand that the $\mathrm{K}$ to 12 program give assurance to the job market that will open to $\mathrm{K}$ to 12 program because, (1) the department of education (DepEd) has entered into an agreement with business organization and local and foreign chambers of commerce and industries that graduate will be employed, the $\mathrm{K}$ to 12 program matches with the competency requirements needed by the labor market (3) $\mathrm{K}$ to 12 is sufficient to prepare $\mathrm{K}$ to 12 graduate in work, (4) help students acquire certificate of competency and national certifications, (5) the $\mathrm{K}$ to 12 will allow graduate to have middlelevel skills and will offer them better opportunities to be gainfully employed or become entrepreneurs, and (6) there will be a school industry partnership in technical-vocational tracks to allow opportunity to give work experience while studying and offers the opportunity be absorbed by the companies.

Table 2b

Parents' Perceptions about the K to 12 Program Implemented in Pikit National High School, Pikit, Cotabato (January 2017)

\begin{tabular}{|c|c|c|c|}
\hline No & Assurance on the Employability of the Graduates & $\begin{array}{l}\text { Weighted } \\
\text { Mean }\end{array}$ & Verbal Description \\
\hline 1 & $\begin{array}{l}\text { I believe that DepEd has entered into an agreement with business organizations } \\
\text { and local and foreign chambers of commerce and industries that graduates of } \mathrm{K} \text { to } \\
12 \text { will be considered for employment. }\end{array}$ & 3.26 & Agree \\
\hline 2 & $\begin{array}{l}\text { I have learned that there will be a matching of competency requirements and } \\
\text { standards so that } 12 \text {-year basic education graduates will have the necessary skills } \\
\text { needed by the labor market. }\end{array}$ & 3.30 & Agree \\
\hline 3 & $\begin{array}{l}\text { I believe that the } \mathrm{K} \text { to } 12 \text { basic education curriculum will be sufficient to prepare } \\
\text { students for work. }\end{array}$ & 3.06 & Agree \\
\hline 4 & $\begin{array}{l}\text { I am aware that the curriculum will enable students to acquire Certificates of } \\
\text { Competency (COCs) and National Certifications (NCs). This will be in accordance } \\
\text { to TESDA training regulations. }\end{array}$ & 3.24 & Agree \\
\hline 5 & $\begin{array}{l}\text { I believe that } \mathrm{K} \text { to } 12 \text { will allow graduates to have middle-level skills and will offer } \\
\text { them better opportunities to be gainfully employed or become entrepreneurs. }\end{array}$ & 3.23 & Agree \\
\hline 6 & $\begin{array}{l}\text { I learned that there will be a school-industry partnership for technical-vocational } \\
\text { tracks to allow students to gain work experience while studying and offer the } \\
\text { opportunity to be absorbed by the companies. }\end{array}$ & 3.33 & Agree \\
\hline
\end{tabular}

\section{Legend:}

Weighted Mean Verbal Description

$3.50-4.00 \quad$ Strongly Agree

2.50-3.49 Agree

$1.50-2.49 \quad$ Disagree

$1.00-1.49 \quad$ Strongly Disagree

\section{Parents' Perception on the $K$ to 12 Program in Helping the Working Students in College and Students Intending to Pursue College}

Table $2 \mathrm{c}$ shows the data in the third subscale of the survey questionnaires in the parents. The parentrespondents "agreed" that the $\mathrm{K}$ to 12 program helps working students intending to pursue college.

It implies that (1) DepEd and CHED offices collaborate to provide more opportunities to working students to attend classes, (2) DepEd and DOLE will facilitate jobs for working students, (3) $\mathrm{K}$ to 12 in accordance with college readiness standards from CHED, and (4) CHED will download its general education subjects to $\mathrm{K}$ to 12 program for mastery of core competencies to $\mathrm{K}$ to 12 graduates. 
Table 2c

Parents' Perceptions about the K to 12 Program Implemented in Pikit National High School, Pikit, Cotabato (January 2017)

\begin{tabular}{|c|c|c|c|}
\hline No & $\begin{array}{c}\text { K to } 12 \text { Program Helps Working Students in College and Students Intending } \\
\text { to Pursue College }\end{array}$ & $\begin{array}{l}\text { Weighted } \\
\text { Mean }\end{array}$ & Verbal Description \\
\hline 1 & $\begin{array}{l}\text { I believe that DepEd is in collaboration with CHED to provide more opportunities } \\
\text { for working students to attend classes. }\end{array}$ & 3.36 & Agree \\
\hline 2 & $\begin{array}{l}\text { I learned that DepEd is working with the Department of Labor and Employment to } \\
\text { ensure that jobs will be available to K to } 12 \text { graduates and that consideration will } \\
\text { be given to working students. }\end{array}$ & 3.20 & Agree \\
\hline 3 & $\begin{array}{l}\text { I believe that the } \mathrm{K} \text { to } 12 \text { basic education curriculum will be in accordance with the } \\
\text { College Readiness Standards from CHED, which sets the skills and competencies } \\
\text { needed of } \mathrm{K} \text { to } 12 \text { graduates who wish to pursue higher education. }\end{array}$ & 3.30 & Agree \\
\hline 4 & $\begin{array}{l}\text { I learned that CHED will download its general education subjects to } \mathrm{K} \text { to } 12 \text {, } \\
\text { ensuring mastery of core competencies for } \mathrm{K} \text { to } 12 \text { graduates. This may lead to a } \\
\text { reduction in the number of years of college courses, resulting to a decrease in } \\
\text { educational expenses of households. }\end{array}$ & 3.23 & Agree \\
\hline
\end{tabular}

Legend:

Weighted Mean Verbal Description

$3.50-4.00 \quad$ Strongly Agree

2.50-3.49 Agree

$1.50-2.49 \quad$ Disagree

$1.00-1.49 \quad$ Strongly Disagree

\section{Parents Perception on the Issues on the Budget for} the $K$ to 12 Program

The last subscale which is the issues on the budget in the $\mathrm{K}$ to 12 program is presented in Table $2 \mathrm{~d}$. It shows that the parents "agreed" to all of the identified statements under this subscale. The parents appeared to have clear understanding that the $\mathrm{K}$ to 12 program, (1) offers free public school education, (2) the graduates will have higher earning potentials, (3) the graduates will have National Certificates with TESDA,(4) there are funds available, and that (5) all costs are borne by the government.

Table 2d

Parents' Perceptions about the K to 12 Program Implemented in Pikit National High School, Pikit, Cotabato (January 2017)

\begin{tabular}{|c|c|c|c|}
\hline No & Issues on the Budget for the $K$ to 12 Program & $\begin{array}{l}\text { Weighted } \\
\text { Mean }\end{array}$ & Verbal Description \\
\hline 1 & $\begin{array}{l}\text { I have learned that the Grades } 11 \text { and } 12 \text { (HS years } 5 \text { and } 6 \text { ) will be offered for free } \\
\text { in public schools. }\end{array}$ & 3.36 & Agree \\
\hline 2 & $\begin{array}{l}\text { I believe that the } \mathrm{K} \text { to } 12 \text { graduates will have higher earning potential as they will } \\
\text { be more competent and skilled. }\end{array}$ & 3.30 & Agree \\
\hline 3 & $\begin{array}{l}\text { I know that the } \mathrm{K} \text { to } 12 \text { graduates will have national certification from TESDA, } \\
\text { which will enable them to have higher employment opportunities. }\end{array}$ & 3.26 & Agree \\
\hline 4 & $\begin{array}{l}\text { I am informed that the Congress has approved budget for } 2012 \text { is P238.8 billion, } \\
\text { including P2.4 billion for kinder. }\end{array}$ & 3.00 & Agree \\
\hline 5 & $\begin{array}{l}\text { I also learned that for } 2016 \text {, the introduction of grade } 11(\mathrm{HS} \text { year } 5) \text { has a } \\
\text { preliminary estimated cost of P38 billion, assuming all costs are borne by the } \\
\text { government(Medium-Term Spending Plan for Basic Education, 2011). }\end{array}$ & 3.00 & Agree \\
\hline
\end{tabular}

\section{Legend:}

Weighted Mean Verbal Description

$3.50-4.00 \quad$ Strongly Agree

2.50-3.49 Agree

$1.50-2.49 \quad$ Disagree

$1.00-1.49 \quad$ Strongly Disagree

\section{Students' Perceptions about the $K$ to 12 Program Implemented in Pikit National High School, Pikit, Cotabato}

Tables $3 \mathrm{a}$ and $3 \mathrm{c}$ present data for the third objective of the study which was to determine the students' perception about the $\mathrm{K}$ to 12 program as implemented in Pikit National High School, Pikit, Cotabato. There were three (3) subscales identified in the survey questionnaire for the student-respondents.

\section{Students' Perception on the K to 12 Program}

Table 3a shows there were some striking findings to emerge because the student-respondents "strongly agreed" that K to 12 offers (statement 1) balance approach to learning and (statement 4) they believed that the $\mathrm{K}$ to 12 program will help them become equipped with the skills, competencies, and receive recognized certificates equivalent to a two-year college degree. 
Table 3a

Students' Perceptions about the K to 12 Program Implemented in Pikit National High School, Pikit, Cotabato (January 2017)

\begin{tabular}{clcc}
\hline No & \multicolumn{1}{c}{ The K to 12 Program } & $\begin{array}{c}\text { Weighted } \\
\text { Mean }\end{array}$ & Verbal Description \\
\hline 1 & $\begin{array}{l}\text { I believe that K to 12 offers a more balanced approach to learning that will } \\
\text { enable us to acquire and master lifelong learning skills (as against a } \\
\text { congested curriculum) for the21st century. }\end{array}$ & 3.53 & Strongly Agree \\
2 & $\begin{array}{l}\text { I believe that the current program crams a 12-year curriculum allowing } \\
\text { students like me to master the competencies I need. }\end{array}$ & 3.20 & Agree \\
3 & $\begin{array}{l}\text { I believe that K to 12 will help in freeing my parents of the burden of } \\
\text { having to spend for college just to make me employable. }\end{array}$ & 3.15 & Agree \\
4 & $\begin{array}{l}\text { I believe that if I complete K to 12, I will be equipped with skills, } \\
\text { competencies, and receive recognized certificates equivalent to a two-year } \\
\text { college degree. }\end{array}$ & 3.55 & Strongly Agree \\
\hline
\end{tabular}

\section{Legend:}

Weighted Mean

$3.50-4.00$

$2.50-3.49$

$1.50-2.49$

$1.00-1.49$

\author{
Verbal Description \\ Strongly Agree \\ Agree \\ Disagree \\ Strongly Disagree
}

However, the students "agreed" to the other statements that (statement 2) $\mathrm{K}$ to 12 allows them to master the competencies they need and (statement 3) that there are less financial burden to the family just to be employed.

\section{Students' Perception on Assurance on the Employability of the Graduates}

Table $3 \mathrm{~b}$ shows the data for the second subscale for the survey questionnaire for the students. It reveals that the student-respondents "agreed" to all of the statements identified in the second subscale on the assurance on the employability of the graduates. The finding is consistent with the findings in parentrespondents' perception on the exact same subscale. This means that the student-respondents also "agreed" to all of the statements identified.

It implies that the student-respondents believed that, (1) the DepEd entered into agreements with the industries for employment opportunities in the $\mathrm{K}$ to 12 graduates, (2) there will be matching competency requirements and standards to the skills needed to the labor market, (3) it is sufficient to prepare students for work, and (4) it allows Certificates of Competencies and National Certificates.

Table 3b

Students' Perceptions about the K to 12 Program Implemented in Pikit National High School, Pikit, Cotabato (January 2017)

\begin{tabular}{|c|c|c|c|}
\hline No & Assurance on the Employability of the Graduates & $\begin{array}{l}\text { Weighted } \\
\text { Mean }\end{array}$ & Verbal Description \\
\hline 1 & $\begin{array}{l}\text { I believe that DepEd has entered into an agreement with business organizations } \\
\text { and local and foreign chambers of commerce and industries that graduates of } \mathrm{K} \text { to } \\
12 \text { will be considered for employment. }\end{array}$ & 3.10 & Agree \\
\hline 2 & $\begin{array}{l}\text { I have learned that there will be a matching of competency requirements and } \\
\text { standards so that } 12 \text {-year basic education graduates will have the necessary skills } \\
\text { needed by the labor market. }\end{array}$ & 2.90 & Agree \\
\hline 3 & $\begin{array}{l}\text { I believe that the } \mathrm{K} \text { to } 12 \text { basic education curriculum will be sufficient to prepare } \\
\text { students for work. }\end{array}$ & 3.40 & Agree \\
\hline 4 & $\begin{array}{l}\text { I am aware that the curriculum will enable students to acquire Certificates of } \\
\text { Competency(COCs) and National Certifications (NCs). This will be in accordance } \\
\text { to TESDA training regulations. }\end{array}$ & 3.33 & Agree \\
\hline 5 & $\begin{array}{l}\text { I believe that } \mathrm{K} \text { to } 12 \text { will allow graduates to have middle-level skills and will offer } \\
\text { them better opportunities to be gainfully employed or become entrepreneurs. }\end{array}$ & 3.18 & Agree \\
\hline 6 & $\begin{array}{l}\text { I learned that there will be a school-industry partnership for technical-vocational } \\
\text { tracks to allow students to gain work experience while studying and offer the } \\
\text { opportunity to be absorbed by the companies. }\end{array}$ & 3.08 & Agree \\
\hline
\end{tabular}

\section{Legend:}

Weighted Mean Verbal Description

$3.50-4.00 \quad$ Strongly Agree

2.50-3.49 Agree

$1.50-2.49 \quad$ Disagree

$1.00-1.49 \quad$ Strongly Disagree 


\section{Students' K to 12 Program Helps Working Students in College and Students Intending to Pursue College}

Table $3 \mathrm{c}$ refers to the third subscale of the survey questionnaire in the student-respondents. Still, the findings to this table are consistent to the findings of the parent-respondents' perceptions. It reveals that the student-respondents "agreed" to all of the statements such as: (1) the DepEd and CHED collaborate with one another to provide more opportunities for working students to attend class, (2) DepEd and DOLE ensure that jobs will be available to $\mathrm{K}$ to 12 graduates, (3) $\mathrm{K}$ to 12 confirms in accordance with the College Readiness Standards in CHED, and (4) CHED download general education to $\mathrm{K}$ to 12 ensuring mastery of core competencies in $\mathrm{K}$ to 12 graduates.

Table 3c

Students' Perceptions about the K to 12 Program Implemented

in Pikit National High School, Pikit, Cotabato (January 2017)

\begin{tabular}{|c|c|c|c|}
\hline No & $\begin{array}{c}\text { K to } 12 \text { Program Helps Working Students in College and Students Intending } \\
\text { to Pursue College }\end{array}$ & $\begin{array}{l}\text { Weighted } \\
\text { Mean }\end{array}$ & Verbal Description \\
\hline 1 & $\begin{array}{l}\text { I believe that DepEd is in collaboration with CHED to provide more opportunities } \\
\text { for working students to attend classes. }\end{array}$ & 3.33 & Agree \\
\hline 2 & $\begin{array}{l}\text { I learned that DepEd is working with the Department of Labor and Employment to } \\
\text { ensure that jobs will be available to K to } 12 \text { graduates and that consideration will } \\
\text { be given to working students. }\end{array}$ & 3.40 & Agree \\
\hline 3 & $\begin{array}{l}\text { I believe that the } \mathrm{K} \text { to } 12 \text { basic education curriculum will be in accordance with the } \\
\text { College Readiness Standards from CHED, which sets the skills and competencies } \\
\text { needed of } \mathrm{K} \text { to } 12 \text { graduates who wish to pursue higher education. }\end{array}$ & 3.15 & Agree \\
\hline 4 & $\begin{array}{l}\text { I learned that CHED will download its general education subjects to } \mathrm{K} \text { to } 12 \text {, } \\
\text { ensuring mastery of core competencies for } \mathrm{K} \text { to } 12 \text { graduates. This may lead to a } \\
\text { reduction in the number of years of college courses, resulting to a decrease in } \\
\text { educational expenses of households. }\end{array}$ & 3.30 & Agree \\
\hline
\end{tabular}

\section{Legend:}

Weighted Mean Verbal Description

$3.50-4.00 \quad$ Strongly Agree

2.50-3.49 Agree

$1.50-2.49 \quad$ Disagree

$1.00-1.49 \quad$ Strongly Disagree

\section{E. Teachers' Perceptions about the $K$ to 12 Program Implemented in Pikit National High School, Pikit, Cotabato}

Table $4 \mathrm{a}$ and $4 \mathrm{~b}$ present data on the fourth objective of the study which was to determine the teachers' perception on the implementation of the $\mathrm{K}$ to 12. The first subscale shows that the teacherrespondents "strongly agreed" to almost all of the statements identified under the $\mathrm{K}$ to 12 program. It means that the teachers believed that (statement 1) K to 12 program provides balance approach to learning, (statement 2) promotes mastery of competencies needed in job markets, and (statement 4) the graduates will be equipped of skills and competencies recognized equivalent to the two-year college degree. Moreover, the teachers "agreed" to only one statement, and (3) the program is less expensive for the parents.

Table 4a

Teachers' Perceptions about the K to 12 Program Implemented in Pikit National High School, Pikit, Cotabato (January 2017)

\begin{tabular}{clccc}
\hline No & \multicolumn{1}{c}{ Statements on the K to 12 Program } & $\begin{array}{c}\text { Weighted } \\
\text { Mean }\end{array}$ & Verbal Description \\
\hline 1 & $\begin{array}{l}\text { I believe that K to } 12 \text { offers a more balanced approach to learning that will enable } \\
\text { our students acquire and master lifelong learning skills (as against a congested } \\
\text { curriculum) for the 21 st century. }\end{array}$ & 3.57 & Strongly Agree \\
2 & $\begin{array}{l}\text { I believe that the current program crams a 12-year curriculum allowing our } \\
\text { students to master the competencies they need. }\end{array}$ & 3.50 & Strongly Agree \\
3 & $\begin{array}{l}\text { I believe that K to 12 will help in freeing the parents of our students of the burden } \\
\text { of having to spend for college just to make their children employable }\end{array}$ & 3.43 & Agree \\
\hline & $\begin{array}{l}\text { I believe that if our students complete K to 12, they will be equipped with skills, } \\
\text { competencies, and recognized certificates equivalent to a two-year college degree. }\end{array}$ & 3.60 & Strongly Agree \\
\hline
\end{tabular}

Legend:

Weighted Mean Verbal Description

$3.50-4.00 \quad$ Strongly Agree

2.50-3.49 Agree

$1.50-2.49 \quad$ Disagree

$1.00-1.49 \quad$ Strongly Disagree 


\section{Teachers' Perception on their Concerns about the} K to 12 Program

Table $4 \mathrm{~b}$ presents the second subscale in the survey questionnaire for the teachers which are the teachers' concerns about the $\mathrm{K}$ to 12 program. It reveals that the teachers "strongly agreed" to half of the statements identified in the subscale about the teachers' concerns about the $\mathrm{K}$ to 12 program, such as, (statement 5) $\mathrm{K}$ to 12 will provide sufficient in-service teacher training implement this program, (statement 6) pre-service training for aspiring teachers will be modified, (statement 8) additional special teachers will be hired and existing teachers were trained to teach core academic subjects, (statement 9) DepEd explores the possibility of utilizing existing technical and higher education teachers to teach Grades 11 to 12 and (statement 10) teacher education institution will also adjust its pre-service program to align it with the needs of the education section.

Table 4b

Teachers' Perceptions about the K to 12 Program Implemented in Pikit National High School, Pikit, Cotabato (January 2017)

\begin{tabular}{|c|c|c|c|}
\hline No & Teachers' Concerns about the K to 12 Program & $\begin{array}{l}\text { Weighted } \\
\text { Mean }\end{array}$ & Verbal Description \\
\hline \multirow[t]{2}{*}{1} & I believe that there will be no additional workload due to the $\mathrm{K}$ to 12 Program. The & & \\
\hline & $\begin{array}{l}\text { Magna Carta for Public School Teachers provides that teachers should only teach } \\
\text { up to six hours a day. }\end{array}$ & 3.33 & Agree \\
\hline 2 & $\begin{array}{l}\text { I am aware that the decongested } \mathrm{K} \text { to } 12 \text { curriculum will allow us to master the } \\
\text { contents and competencies that we will develop among the students, and will } \\
\text { enable them to focus on their areas of expertise. }\end{array}$ & 3.40 & Agree \\
\hline 3 & $\begin{array}{l}\text { I learned that the } \mathrm{K} \text { to } 12 \text { Program will not result in teacher salary increase because } \\
\text { there will be no additional teaching load or additional teaching hours. }\end{array}$ & 3.47 & Agree \\
\hline 4 & $\begin{array}{l}\text { I believe that salary increases for other reasons, such as the Salary Standardization } \\
\text { Law, inflation, and promotion, may apply. }\end{array}$ & 3.47 & Agree \\
\hline 5 & $\begin{array}{l}\text { I know that we will be given sufficient in-service training to implement this } \\
\text { program. }\end{array}$ & 3.57 & Strongly Agree \\
\hline 6 & $\begin{array}{l}\text { I believe that the preservice training for aspiring teachers will also be modified to } \\
\text { conform to the requirements of the program. }\end{array}$ & 3.60 & Strongly Agree \\
\hline 7 & $\begin{array}{l}\text { I was able to train in the training of grades } 1 \text { and } 7 \text { teachers conducted at the } \\
\text { regional and division levels for the whole month of May } 2012 \text {. }\end{array}$ & 2.97 & Agree \\
\hline 8 & $\begin{array}{l}\text { I know that the additional special teachers were hired and existing teachers were } \\
\text { trained to teach the core academic subjects and electives that are offered in grades } \\
11 \text { and } 12 \text { (HS years } 5 \text { and } 6 \text { ). }\end{array}$ & 3.63 & Strongly Agree \\
\hline 9 & $\begin{array}{l}\text { I believe that the DepEd is exploring the possibility of utilizing existing technical } \\
\text { and higher education teachers to teach grades } 11 \text { and } 12 \text { (HS year } 5 \text { and } 6 \text { ), } \\
\text { especially during the transition period. }\end{array}$ & 3.70 & Strongly Agree \\
\hline 10 & $\begin{array}{l}\text { I am aware that the teacher education institutions will also adjust its preservice } \\
\text { programs to align it with the needs of the education sector. }\end{array}$ & 3.57 & Strongly Agree \\
\hline
\end{tabular}

Legend:

Weighted Mean Verbal Description

$3.50-4.00 \quad$ Strongly Agree

2.50-3.49 Agree

$1.50-2.49 \quad$ Disagree

$1.00-1.49 \quad$ Strongly Disagree

Additionally, the teachers "agreed" the other half of the statements in the second subscale, which were, (statement 1) there were no additional workload due to $\mathrm{K}$ to 12 program, (statement 2 ) $\mathrm{K}$ to 12 helps students master the contents and competencies that will enable them to focus on their area of expertise, (statement 3) the $\mathrm{K}$ to 12 does not result in teacher salary increase, (statement 4) salary increase are based on Salary Standardization, laws, inflations, and promotion, and (statement 7 ) $\mathrm{K}$ to 12 will provide trainings.

\section{F. Problems Encountered by the Respondents in the Implementation of the $K$ to 12 Program}

Table 5a to $5 \mathrm{c}$ show the problems encountered by the respondents (parents, students, and teachers).

Problems Encountered by the Selected Parents in the K to 12 Program
Table 5a reveals that the problems identified by 19 or $63.30 \%$ of the parents were, (1) the program was expensive. According to a follow-up question about the said problem, the findings in this section were not congruent to the statements that the government allocated funds to support the program. Another problem identified was 8 or $26.70 \%$ of the parents believed that, (2) the resources will be used. This problem was identified in relation to the problem that the program was expensive, considering that the program intends graduate to be job-ready for their children. Hence, they get compelled to use up whatever resources they have just to support the education of the Grade 11 children. The last problem to emerge was about (3) the time management. The students need more time to catch up with the schedules and sometimes would extend more time that cause hassles to both the parents and their children. 
Table 5a

Problems Encountered by the Selected Parents of the Grade 11 Students in Pikit National High School, Pikit, Cotabato (January 2017)

\begin{tabular}{clccc}
\hline No & & Problems Encountered & Frequency & Percentage \\
\hline 1 & Expensive & 19 & 63.30 \\
2 & A lot of resources will be used & 8 & 26.70 \\
3 & Time Management & TOTAL & 3 & 10.00 \\
\hline & & TO & $\mathbf{1 0 0 . 0 0}$ \\
\hline
\end{tabular}

G. Problems Encountered by the Selected Grade 11 Students in the $K$ to 12 Program

Table $5 \mathrm{~b}$ on the other hand, reveals that the students believed that the National High School in Pikit, Cotabato still has (1) poor facilities (i.e. 21 or $55.00 \%$ of the students), (2) insufficient rooms (16 or $40 \%$ ) and 2 or $5 \%$ believed that there were, (3) insufficient equipment for laboratories and textbooks
( 2 or $5 \%$ of them). Moreover, Table $5 \mathrm{c}$ reveals the problem identified by the teachers in Pikit National High School. It shows that 15 or $50 \%$ of the teacherrespondents believed that their main problem was, (1) lack of classrooms \& poor facilities, while there were, (2) insufficient numbers of Senior High School Teachers, and lastly, 5 or $16.7 \%$ believed (3) there were delays in salary.

Table 5b

Problems Encountered by the Selected Grade 11 Students in Pikit National High School, Pikit, Cotabato (January 2017)

\begin{tabular}{clccc}
\hline No & & Problems Encountered & Frequency & Percentage \\
\hline 1. & Poor facilities & 22 & 55.00 \\
2. & Insufficient rooms & 16 & 40.00 \\
3. & Insufficient equipment for laboratory & 2 & 5.00 \\
\hline \multicolumn{2}{r}{ TOTAL } & $\mathbf{4 0}$ & $\mathbf{1 0 0 . 0 0}$ \\
\hline
\end{tabular}

Table 5c

Problems Encountered by the Selected Teachers of the Grade 11 Students in Pikit National High School, Pikit, Cotabato (January 2017)

\begin{tabular}{clcc}
\hline No & \multicolumn{1}{c}{ Problems Encountered } & Frequency & Percentage \\
\hline 1 & Lack of classrooms and poor facilities & 15 & 50.00 \\
2 & Insufficient numbers of Senior High School teachers & 10 & 33.30 \\
3 & Delayed salary & 5 & 16.70 \\
\hline & TOTAL & $\mathbf{3 0}$ & $\mathbf{1 0 0 . 0 0}$ \\
\hline
\end{tabular}

H. Recommendations for the Problems Encountered by the Respondents in the Implementation of the $K$ to 12 Program

The last groups of tables and findings provide data for the last objective of this study which was the parents, students, and teachers recommendations to the problems encountered by them in the implementation of $\mathrm{K}$ to 12 .
Parents' Recommendations on the Problems they Encountered on the $K$ to 12 Program

First for the problems on expenses the government should provide free tuition fees and fewer projects should be required to the students as recommended by 15 or $50 \%$ of the parentsrespondents.

Table 6a

Recommendations for the Problems Encountered by the Selected Parents of the Grade 11 Students in Pikit National High School, Pikit, Cotabato (January 2017)

\begin{tabular}{clcc}
\hline No & \multicolumn{1}{c}{ Recommendations } & Frequency & Percentage \\
\hline 1. & Free tuition and less project & 15 & 50.00 \\
2. & Government having seminars regarding the K to12 program & 8 & 26.70 \\
3. & Provide DepEd learning materials & 4 & 13.30 \\
4. & Classes will start earlier and dismisses as earlier than 5 pm & 3 & 10.00 \\
\hline \multicolumn{1}{c}{ TOTAL } & $\mathbf{3 0}$ & $\mathbf{1 0 0 . 0 0}$ \\
\hline
\end{tabular}

Moreover, 8 or $26.70 \%$ of the students suggested that, (2) the government should have seminars regarding the $\mathrm{K}$ to 12 program, the other 4 or $13.30 \%$ of the parents believed that (3) DepEd should provide learning materials and lastly, 3 or $10 \%$ of the parents suggested that it (4) classes start early, it should also be dismissed earlier than $5 \mathrm{pm}$. 
Students' Recommendations on the Problems they Encountered on the $K$ to 12 Program

On the other hand, Table $6 \mathrm{~b}$ shows the recommendations of the students-respondents were first, 27 or $67.50 \%$ of them recommend that room facilities must be prepared, second, 10 or $25.00 \%$ recommend providing enough room for them, and their last recommendation is that 3 or $7.50 \%$ believed that they should be provide with equipment for hands-on laboratories such as computers and textbooks.

Table 6b

Recommendations for the Problems Encountered by the Selected Grade 11 Students in Pikit National High School, Pikit, Cotabato (January 2017)

\begin{tabular}{clccc}
\hline No & \multicolumn{1}{c}{ Recommendations } & Frequency & Percentage \\
\hline 1 & Provide enough rooms & 10 & 25.00 \\
2 & $\begin{array}{l}\text { Room facilities must be prepared } \\
3\end{array}$ & $\begin{array}{l}\text { Provide equipment for hands-on laboratories such as computers and } \\
\text { textbooks }\end{array}$ & 27 & 67.5 \\
\hline & \multicolumn{1}{c}{ TOTAL } & $\mathbf{4 0}$ & 7.50 \\
\hline
\end{tabular}

Teachers' Recommendations on the Problems they Encountered on the $K$ to 12 Program

Moreover, the teachers' recommendations regarding on the problems encountered are showed on Table $6 \mathrm{c}$. It revealed that there were 9 or $30.30 \%$ of them who recommended that, (1) the Philippine
Government should increase the budget for DepEd. The second recommendation was to hire additional teachers, and (3) provide enough classrooms with same percentage 8 or $26.70 \%$, and 5 or $16.70 \%$ teachers recommended, (4) providing the necessary equipment they need.

Table 6c

Recommendations for the Problems Encountered by the Teachers of the Grade 11 Students in Pikit National High School, Pikit, Cotabato (January 2017)

\begin{tabular}{clcc}
\hline No & \multicolumn{1}{c}{ Recommendations } & Frequency & Percentage \\
\hline 1 & Increase budget for DepEd & 9 & 30.00 \\
2 & Hire additional teachers & 8 & 26.70 \\
3 & Provide enough classroom & 8 & 26.70 \\
4 & Provide the necessary equipment they need & 5 & 16.70 \\
\hline \multicolumn{2}{r}{ TOTAL } & $\mathbf{3 0}$ & $\mathbf{1 0 0 . 0 0}$ \\
\hline
\end{tabular}

\section{CONCLUSIONS RECOMMENDATIONS}

AND

This study entitled, "Perceptions of Parents, Students, and Teachers on the Implementation of the K to 12 Program in Pikit National High School, Pikit, Cotabato", specifically aimed to: (1) determine the socio-demographic characteristics of the respondents (parents, students, and teachers); (2) determine the parents' perceptions on the $\mathrm{K}$ to12 program; (3) determine the students' perceptions on the $\mathrm{K}$ to 12 program; (4) determine the teachers' perceptions on the $\mathrm{K}$ to 12 program; (5) problems encountered by the respondents in the implementation of the $\mathrm{K}$ to 12 programs; and (6) recommendations of the respondents in the implementation of the $\mathrm{K}$ to 12 programs.

This study utilized the descriptive research design in order to determine the socio-demographic characteristics of the respondents and their perceptions on the $\mathrm{K}$ to 12 programs. The study selected 30 samples from the parent-respondents, 40 for the student-respondents, and 30 for the teacherrespondents using the purposive sampling procedure and complete enumeration for the teachers. The study was conducted at Pikit National High School in Pikit, Cotabato. The perceptions of the parents, students, and teachers were obtained using self-made survey questionnaires appropriate for each group of respondents. The data was analyzed using the frequency distribution, percentages, and weighted means.

The gathered data which were analyzed yielded the following results:

1. Socio-demographic characteristics of the respondents:

a. The parent-respondents were mostly aged 36 to 40 years old, mothers, Islam in religion, Maguindanaon, mostly high school graduates, and housekeepers for female respondents and farmers for male respondents;

b. The student-respondents were equally selected from the groups of Grade 11 which means 10 for each from the ABM, Humms, ICT, and STEM; mostly 17 years old, female, Islam in religion, and Maguindanaon; and

c. The teacher-respondents were mostly 26 to 30 years old, consisting the same numbers of female and male teachers, Christian in religion mostly Maguindanaon, college graduates, teacher- 1 and worked between 7 to 11 months;

2. Based on the parents' perceptions on the $\mathrm{K}$ to 12 program, they "agreed" to the four identified subscales, namely: (1) K to 12 program in general, (2) assurance on the employability of the graduates, (3) $\mathrm{K}$ to 12 program helps working students intending to pursue college, and (4) issues on the budget for the $\mathrm{K}$ to 12 program.

3. The student-respondents "strongly agreed" on the first subscale, they believed that the $\mathrm{K}$ to 12 
program offers, (1) balance approach to learning, and (2) they believed that the K to 12 program will help them become equipped with the skills, competencies, and receive recognized certificates equivalent to a two-year college degree. Moreover, the student-respondents "agreed" to all of the statements identified in the second subscale (assurance on the employability of the graduates) and third i.e. the $\mathrm{K}$ to 12 program helps working students in college and students intending to pursue college.

4. Based on the findings, the teachers "strongly agreed" to almost all of the statements on the first subscale of the survey questionnaire which was the General Perception on $\mathrm{K}$ to 12 program. Furthermore, the teachers also "strongly agreed" to half of the statements identified in the last subscale about the teachers' concerns on the K to 12 .

5. Problems encountered by the respondents:

a. Parents: Expensive, a lot of resources will be used and time management;

b. Students: Poor facilities, insufficient rooms, and insufficient equipment for laboratory and additional textbooks; and

c. Teachers: Lack of classrooms and poor facilities, delayed salary, insufficient numbers of Senior High School Teachers.

6. Recommendations for the Problems encountered:

a. Parents: Free tuition fees and fewer projects, government should conduct seminars to parents, regarding the $\mathrm{K}$ to 12 program, and classes will start earlier and dismissed earlier than $5 \mathrm{pm}$, and provide additional learning materials;

b. Students: Provide enough rooms; provide equipment for hands-on laboratories such as computers and textbooks, and room facilities must be prepared; and

c. Teachers: Increase budget for DepEd, hire additional teachers, provide enough classrooms.

The most striking findings to occur in this study was that the parents, students, and teachers appeared to understand the $\mathrm{K}$ to 12 program as evidenced by their agreements to all of the statements identified in the survey questionnaire. On the contrary, they still felt there were some areas needing improvements and concerns to be addressed. Therefore, the parents, students, and teachers in Pikit National High School, Pikit, Cotabato identified some of the problems such as the $\mathrm{K}$ to 12 programs was expensive, poor and insufficient facilities, lack of classrooms and laboratory equipment, delays in salary, and insufficient numbers of teachers in Senior High School. Moreover, the respondents also identified some of the ways to counter such problems by suggesting some recommendations to provide solutions for the problems they identified.

In view of the findings and conclusions, the study recommends the following:

1. The findings of the study reveal no disagreements from the respondents. Hence, future studies should be conducted to larger groups of stakeholders to elicit sufficient data to generalize the results.

2. Since there were problems identified by the different stakeholders (parents, students, and teachers), it should be suggested to the Philippine government under the Department of Education to provide all the identified problems to make the $\mathrm{K}$ to 12 program implementation more effectively.

3. It is recommended that the Philippine government should allocate budget for an academic institution to conduct a nation-wide research to conduct researches on the effectiveness of the $\mathrm{K}$ to 12 program and to allow the stakeholders to share their sentiments about the deficiencies and/or inadequacy of the facilities to accommodate the needs of the growing number of student population all over the country.

\section{REFERENCES}

[1] Bongcales, I. 2014. School Workers Affected by K to 12 Face an Uncertain Future. Retrieved January 2, 2016, from http://www.philstar.com/.

[2] Department of Education. 2010. Discussion Paper on the Enhanced $\mathrm{K}+12$ basic Education Program. Department of Education. Retrieved January 2, 2016, from http://ceap.org.ph/.

[3] Department of Education. 2012. Frequently Asked Questions on K to 12 Program. Retrieved January 2, 2017, from http://www.deped.gov.ph.

[4] Duncan, A. 2009. Reauthorization of ESEA: Why We Can't Wait. SecretaryArne. Duncan's Remarks at the Monthly Stakeholders Meeting. Retrieved January 2, 2016, from Available on: http://www.ed.gov/.

[5] Flores, H. 2014. DepEd Moves to Minimize Displacement of Teachers Due to K-12. The Philippine Star. Retrieved January 2, 2016, from http://www.philstar.com/.

[6] Official Gazette. 2013. Implementing Rules and Regulations of the Enhanced Basic Education Act of 2013. Retrieved January 2, 2016, from http://www.gov.ph/.

[7] Pandulo, N. 2012. Perception of Parents and Senior Students on the Enhanced $K$ to 12 Program of the Department of Education (Masters of Arts in Education) Education Management.

[8] Philippine Institute for Development Studies. 2012 Enhanced $K$ to 12 Basic Education Program: Opportunities and challenges. Retrieved January 2, 2016, from http://dirp3.pids.gov.ph.

[9] UNESCO Report. 2014. Philippine Education for All 2015: Implementation and Challenges. Retrieved January 2, 2016, from http://planipolis.iiep.unesco.org. 